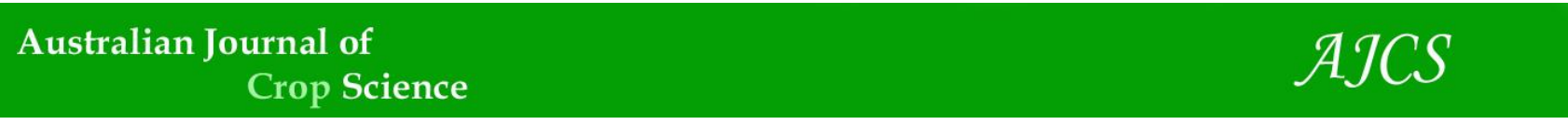

AJCS 15(04):543-552 (2021)

ISSN:1835-2707

doi: 10.21475/ajcs.21.15.04.p2831

\title{
Cassava wastewater as ecofriendly and low-cost alternative to produce lettuce: impacts on soil organic carbon, microbial biomass, and enzymatic activities
}

\section{Diogo Paes da Costa ${ }^{1}$, Janisson Bispo Lino ${ }^{2}$, Neyla Thayná Lima ${ }^{1}$, Cícero Luiz Franco Junior ${ }^{1}$, Fabiano da Silva Brito ${ }^{1}$, Lucas Felipe Prohmann Tschoeke ${ }^{2}$, Rafaela Felix da Franca ${ }^{1}$, Renata Oliveira Silva ${ }^{1}$, Erika Valente de Medeiros ${ }^{1}$}

\author{
${ }^{1}$ Laboratory of environmental Microbiology and Enzymology, Federal Rural University of Pernambuco, Garanhuns \\ 55292-270, Brazil \\ ${ }^{2}$ Laboratory of Toxicology, Federal Rural University of Pernambuco, Garanhuns 55292-270, Brazil
}

*Corresponding author: evmbio@gmail.com

\begin{abstract}
The processing of cassava roots for starch extraction in factories generates a large amount of cassava wastewater (CW), which is rich in nutrients that are beneficial to plants. The reuse of this agro-industrial by-product is important for farmers and the environment as an alternative means to support soil fertility and plant production. Lettuce is the most important salad vegetable grown in the world. The objective of this study was to evaluate the impact of $\mathrm{CW}$ doses on soil organic carbon, basal respiration, microbial biomass, enzymatic activities, and lettuce growth in an Entisol. The experiment was conducted in pots in a greenhouse at room temperature in a completely randomized design with ten replications. The treatments consisted of the application of $\mathrm{CW}$ in increasing volumes that corresponded to fractions of the field capacity (FC) of the soil $\left(100 \% \mathrm{FC}=206.6 \mathrm{ml} \mathrm{dm}^{-3}\right)$ : $0 \%($ negative control), $10 \%, 20 \%, 30 \%, 40 \%$, and $50 \%$ of field capacity (FC) per pot. An additional treatment without $\mathrm{CW}$ was also included, applying only $1.0 \mathrm{~g}$ of mineral fertilizer per pot $(20 \% \mathrm{~N}, 10 \% \mathrm{P}$, and $20 \% \mathrm{~K})$. After 28 days of emergence, the $10 \% \mathrm{FC}$ treatment responded similarly to mineral fertilizer, increasing the length of the branches $(+42 \%)$, number of leaves $(+45 \%)$, aerial fresh matter $(+202 \%)$ and the concentrations of Chlorophyll A (+33\%), and Chlorophyll B $(+40 \%)$, in addition to soil organic carbon (+15\%), all compared to the control. The enzymatic activities in the soil were shown to be sensitive to $\mathrm{CW}$ dosage, especially for urease, which grew linearly as a function of the increased $\mathrm{pH}$ and $\mathrm{K}^{+}$ions in the soil with the application of $\mathrm{CW}$. The dose $20.7 \mathrm{ml} \mathrm{CW} \mathrm{dm}^{-3}(10 \%$ FC) was that most increased plant variables, but the nutritional status of the soil and microbial activities benefited more from higher doses, starting from $30 \% \mathrm{FC}$, a scenario that could benefit plants more in future phenological stages, when there will be greater nutritional demand.
\end{abstract}

Keywords: Manihot esculenta residue; Lactuca sativa; soil conservation; multivariate analysis.

Abbreviations: CW_cassava wastewater; FC_field capacity; BL_lettuce main branch length; NL_lettuce number of leaves; SD_lettuce stalk diameter; AFM_lettuce aerial fresh matter; RFM_lettuce fresh root matter; ADM_lettuce aerial dry matter;

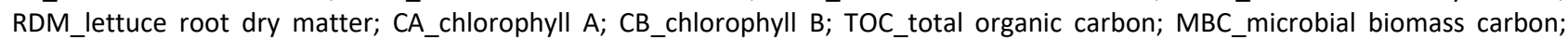
BRS_basal respiration of the soil; Paci_soil acid phosphatase; Palk_soil alkaline phosphatase; Ure_soil urease activity.

\section{Introduction}

Cassava (Manihot esculenta Crantz.) is the most important tuberous root crop in the world, corresponding to the main source of carbohydrates for the population of many countries (Zainuddin et al., 2018). The by-products from its production and processing have gained wide prominence in the scenario of agricultural sustainability, mainly through reuse to produce bioethanol, biodiesel and biogas (Ratnadewi et al., 2016) and use as a biofertilizer in tropical soils that are poor in nutrients (Moura et al., 2018). Research carried out in China has shown how promising and renewable these activities are, also highlighting the use of liquid waste to mitigating the emission of greenhouse gases (Ye et al., 2017; Jiao et al., 2018).

Given the progress and increase of cassava-producing areas, problems have arisen due to the incorrect disposal of its waste, which has caused serious impacts to the environment and its organisms (Oliveira and Jucá, 2004). Cassava wastewater (CW) is the main by-product from the production of manioc flour and starch, corresponding to about $30 \%$ of its total mass (Andrade et al., 2017). This residue is rich in proteins, lipids, carbohydrates, sugars (fructose and glucose), organic matter and hydrocyanic acid (Rosa et al., 2016; Gomes et al., 2016), in addition to a large amount of macro- and micronutrients essential to plants (Dantas et al., 2014; Ribas et al., 2010).

In this context, many studies have evaluated the potential use of $\mathrm{CW}$ in agriculture for various purposes, such as plant nutrition (Barreto et al., 2014; Dantas et al., 2017), biological defense (Nasu et al., 2015; Santos et al., 2016) and for improving soil quality, since it promotes an increase in microbial biomass and organic carbon content (Moura et al., 2018). The agricultural use of $\mathrm{CW}$ is also desirable due to its 
low cost, which could be a viable way to promote crop development through the partial replacement of synthetic commercial fertilizers (Santos et al., 2010). However, there is still a gap in our knowledge regarding CW application to sandy soils and the growth of horticultural crops, such as lettuce (Lactuca sativa L.), the most widely cultivated and consumed vegetable in Brazil (Scherer et al., 2016).

Considering the factors listed above, the hypothesis was raised that the application of $\mathrm{CW}$ doses in a sandy soil cultivated with lettuce would increase significantly the soil base saturation and enzyme activity, both important variables in lettuce good nutrition. The purpose of this study was to test the correlations between these variables and find the main benefits and disadvantages of $\mathrm{CW}$ for the soil and lettuce cultivation.

\section{Results}

\section{Lettuce growth}

The lettuce main branch length (BL) and number of leaves $(\mathrm{NL})$ were the phenotypic attributes that most demonstrated a significant response to CW application (Fig $1 \mathrm{~A}$ and Fig 1B). For these variables, a dosage of around $10 \%$ FC showed the best efficiency for providing significantly higher results than the negative control and was not distinguishable from treatment with mineral fertilizer. In these cases, the $10 \%$ FC treatment was sufficient to significantly increase the length of the branches and the number of leaves by $42 \%(8.6 \mathrm{~cm}$ to $12.17 \mathrm{~cm}$ ) and $45 \%$ (11 to 16 leaves), respectively with respect to the control (Table 1 ).

Despite the high variability of some plant developmental data, important gains were observed in treatments with cassava wastewater (Table 1). The results showed that aerial fresh matter (AFM) from plants that received $10 \%$ FC weighed on average $28.96 \mathrm{~g}$, while the control weighed only $9.6 \mathrm{~g}$, an increase of $202 \%$ (Table 1). This CW dosage was more efficient for AFM, considering that a similar response only occurred at $50 \% \mathrm{FC}$, weighing on average $24.6 \mathrm{~g}$ (+144\%). Similarly, with the $10 \%$ FC dosage, chlorophylls A and $B$ showed an increase of $33 \%$ and $40 \%$, respectively, with regard to the control and remained practically stable at subsequent $\mathrm{CW}$ dosages (Table 1 ).

After a stationary phase $\left(75 \mathrm{ml} \mathrm{kg}^{-1}\right.$ soil or $\left.36 \% \mathrm{FC}\right)$, the $\mathrm{BL}$ continued to grow significantly more than in the negative control (Fig 1A). Above $10 \% \mathrm{CW}$, the NL decreased and was not different from the control (Fig 1B). As the weights did not differ, the results suggest that the $20.7 \mathrm{ml} \mathrm{dm}^{-3} \mathrm{CW}$ at $10 \%$ FC application led to the growth of thinner branches with more leaves, similar to the treatments with NPK, contrasting from the negative control.

\section{Soil chemical and microbial attributes}

The soil chemical attributes $\mathrm{pH}$, potential acidity of soil $\left(\mathrm{H}^{+}+\mathrm{Al}^{3+}\right), \mathrm{Na}^{+}, \mathrm{K}^{+}$, and total organic carbon (TOC) content showed significant differences among $\mathrm{CW}$ dosages, as well as soil basal respiration (SBR) and enzymatic activities, according to the F-test $(p<0.05)$ (Table 1$)$.

Soil acidity declined significantly with the addition of $\mathrm{CW}$, especially at $30 \%$ and $40 \% \mathrm{FC}$, where it practically neutralized the $\mathrm{H}^{+}+\mathrm{Al}^{3+}$ ions in the soil (Fig 1C). Also, in this range, $\mathrm{K}^{+}$content reached its peak, revealing the potential of $\mathrm{CW}$ as a tool for soil correction (Fig 1D). Moreover, the CW demonstrated strong potential to increase soil pH (Fig 1E), with cases where it raised the $\mathrm{pH}$ from 5.2 to 6.4 at the higher dosage $(50 \% \mathrm{FC})$, reporting a positive and strongly adjusted correlation $\left(R^{2} \sim 1\right)$.

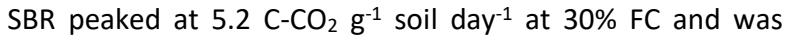
significantly higher than the control and $10 \% \mathrm{FC}$ treatments (Fig 1F). TOC showed a rapid increase at $10 \%$ FC $\left(8.1 \mathrm{~g} \mathrm{~kg}^{-1}\right)$ with a maximum between $10 \%$ to $30 \%$ FC $\left(8.2 \mathrm{~g} \mathrm{~kg}^{-1}\right)$, differing significantly compared to the control $\left(7.0 \mathrm{~g} \mathrm{~kg}^{-1}\right)$ (Fig 1G). From these intervals, the TOC decreased again, such as microbial biomass carbon (MBC). The results provide consistent evidence of how CW doses equivalent to $30 \%$ affect the behavior of the soil microbial communities studied.

\section{Soil enzymatic activities}

The activity of both phosphatases decreased with CW, reaching minimum values for treatments with mineral fertilizer (NPK) or $40 \%$ FC (Fig $1 \mathrm{H}$, Fig 1I). The alkaline phosphatase activity in the control treatment was significantly higher than in all other treatments (Fig $1 \mathrm{H})$. The average activity of acid phosphatase between $0 \%$ and $20 \%$ FC was similar, corresponding to a significantly higher average than the range found between $30 \%$ and $50 \%$ FC (Fig 11). Urease increased linearly as CW dosages increased (Fig 1J), recording a maximum activity of $337 \mu \mathrm{g} \mathrm{NH} \mathrm{NH} \mathrm{g}^{-1} \mathrm{dwt}$ $2 \mathrm{~h}^{-1}$ at a relative dosage of $50 \% \mathrm{FC}$, which represented a growth of $666 \%$ compared to the control.

\section{Multivariate analysis}

The Constrained Analysis of Principal Coordinates (CAP) was based on Euclidean distance, where the two main axes in biplot explained $75 \%$ of the total variance and $96 \%$ of the constrained (vectors) variance of eigenvalues (Fig 2). The Permutational Multivariate Analysis of Variance (PERMANOVA) revealed a good fit to the model, with $\mathrm{R}^{2}=$ 0.72 for the plant attributes explanatory model by the Adonis test (Table 2), being a function of soil bio-chemical attributes (constraining variables). This indicated that lettuce development was influenced by chemical properties or soil enzymatic activities, with significant contributions of $\mathrm{pH}$, soil basal respiration (SBR) and $\mathrm{Na}$ (Table 3). Other important attributes for lettuce vegetative development were soil acid phosphatase (Pac), soil urease (Ure), CW doses, total organic carbon (TOC), soil alkaline phosphatase (Palk), potassium (K), and microbial biomass carbon (MBC), in decreasing order (Table 3).

PERMANOVA showed the influence of axis 1 on the model was significant $(p<0.015)$, by the pseudo- $F$ statistic. Therefore, the variables with higher scores on this axis are more important to explain the multivariate model. In this case, the plant attributes that responded well to soil attributes were (in decreasing order) AFM, root fresh matter (RFM), number of leaves (NL), main branch length (MBL), chlorophyll $A(C A)$, root dry matter (RDM), aerial dry matter (ADM), chlorophyll B (CB), and stalk diameter (SD) (Table 4). A multiple correlation was made among all variables to highlight the most important interactions, demonstrating strong positive interactions between $\mathrm{pH}, \mathrm{CW}$ dosage, $\mathrm{K}$ concentrations in the soil and urease activity (Fig 3 ). The multiple correlation between the most significant variables revealed that lettuce $\mathrm{MBL}$ was more closely related to soil $\mathrm{pH}$ increase, while SBR was to $\mathrm{K}^{+}$contents (Fig 4). In addition, there was a strong positive influence of $\mathrm{CW}$ dosage on $\mathrm{pH}, \mathrm{K}^{+}$ion concentration and soil urease activity, and a negative one on potential soil acidity. The strong correlation between these variables was tested by analysis of variance, 
Table 1. Mean, standard deviation (S), coefficient of variation (CV\%), and statistical test of the physiological data of lettuce plants (1 - 9), chemical attributes (10 - 16) and enzymatic activities (18 - 19) in soil cultivated with lettuce under increasing doses of cassava wastewater. Treatments that significantly responded to CW doses were submitted to regression analysis and tests on multiple pairs of means.

\begin{tabular}{|c|c|c|c|c|c|c|c|c|c|c|c|c|}
\hline & \multirow[t]{2}{*}{ Variable } & \multicolumn{7}{|c|}{ Dosage - \% FC (206.6 ml dm-3 soil) } & \multirow[b]{2}{*}{ mean } & \multirow[b]{2}{*}{$\mathrm{S}$} & \multirow[b]{2}{*}{$\mathrm{CV} \%$} & \multirow[b]{2}{*}{ test } \\
\hline & & NPK & $0 \%$ & $10 \%$ & $20 \%$ & $30 \%$ & $40 \%$ & $50 \%$ & & & & \\
\hline 1 & Chlorophyll A - CA $\left(\mu \mathrm{g} \mathrm{cm}^{-2}\right)$ & 20.3 & 15.4 & 20.5 & 18.65 & 17.7 & 19.7 & 20.8 & 19.01 & 2.02 & 9.7 & ns \\
\hline 2 & Chlorophyll B - CB $\left(\mu \mathrm{g} \mathrm{cm}^{-2}\right)$ & 3.4 & 2.75 & 3.85 & 3.15 & 3.1 & 3.85 & 3.6 & 3.39 & 0.45 & 13.7 & ns \\
\hline 3 & Aerial Dry Matter - ADM (g) & 2.57 & 0.7 & 2.42 & 0.92 & 0.63 & 1.68 & 2.11 & 1.58 & 0.76 & 64.7 & ns \\
\hline 4 & Root Dry Matter - RDM (g) & 2.57 & 2.13 & 3.15 & 2 & 1.05 & 2.32 & 2.11 & 2.19 & 0.67 & 42.6 & ns \\
\hline 5 & Aerial Fresh Matter - AFM (g) & 22.13 & 9.6 & 28.96 & 13.3 & 12.11 & 15.98 & 24.62 & 18.10 & 8.55 & 65.5 & ns \\
\hline 6 & Root Fresh Matter - RFM (g) & 18.51 & 10.08 & 11.93 & 10.83 & 6.59 & 11.82 & 9.78 & 11.36 & 1.96 & 44.6 & ns \\
\hline 7 & Main Branch Length - MBL (cm) & 11.23 & 8.57 & 12.17 & 10.63 & 10.1 & 12.23 & 12.3 & 11.03 & 1.51 & 13.2 & $\mathrm{t}$ \\
\hline 8 & Number of Leaves - NL & 13.67 & 11 & 16 & 12.33 & 11.33 & 11 & 12.33 & 12.52 & 1.9 & 11 & $\mathrm{t}$ \\
\hline 9 & Stalk Diameter - SD $(\mathrm{cm})$ & 0.9 & 0.78 & 1 & 0.93 & 0.8 & 0.73 & 0.78 & 0.85 & 0.11 & 16.3 & ns \\
\hline 10 & $\mathrm{H}^{+}+\mathrm{Al}^{\mid+}\left(\mathrm{cmolc} \mathrm{dm}^{-3}\right)$ & 0.17 & 0.17 & 0.17 & 0.06 & 0.06 & 0 & 0 & 0.09 & 0.08 & 75 & $t$ \\
\hline 11 & $\mathrm{~K}^{+}\left(\mathrm{cmolc} \mathrm{dm}^{-3}\right)$ & 0.05 & 0.06 & 0.05 & 0.19 & 0.23 & 0.23 & 0.24 & 0.15 & 0.09 & 28.5 & $\mathrm{t}$ \\
\hline 12 & $\mathrm{Na}^{+}\left(\mathrm{cmolc} \mathrm{dm}^{-3}\right)$ & 0.21 & 0.19 & 0.3 & 0.19 & 0.17 & 0.26 & 0.28 & 0.23 & 0.05 & 8.6 & ns \\
\hline 13 & $\mathrm{pH}$ & 5.1 & 5.2 & 5.48 & 5.63 & 5.68 & 5.96 & 6.38 & 5.63 & 0.41 & 2.8 & $\mathrm{t}$ \\
\hline 14 & BRS $\left[\mathrm{C}-\mathrm{CO}_{2}\left(\mathrm{mg} \mathrm{CO}_{2} \mathrm{~g}^{-1} \mathrm{day}^{-1}\right)\right]$ & 4.25 & 1.63 & 3.57 & 4.02 & 5.18 & 3.55 & 3.95 & 3.74 & 1.15 & 12.1 & $t$ \\
\hline 15 & Microbial Biomass Carbon $\left(\mathrm{g} \mathrm{kg}^{-1}\right)$ & 6.25 & 12.92 & 11.25 & 11.04 & 8.33 & 6.77 & 8.33 & 9.27 & 2.32 & 16.2 & ns \\
\hline 16 & Total Organic Carbon $\left(\mathrm{g} \mathrm{kg}^{-1}\right)$ & 6.92 & 7.02 & 8.1 & 7.66 & 8.19 & 6.95 & 7.63 & 7.50 & 0.52 & 3.3 & $\mathrm{t}$ \\
\hline 17 & Alkaline Phosphatase $\left(\mu \mathrm{g}\right.$ PNF g ${ }^{-1}$ soil $\left.^{-1}\right)$ & 6.41 & 74.38 & 30.75 & 31.5 & 12.59 & 4.16 & 9.96 & 24.25 & 25.69 & 34.5 & d \\
\hline 18 & Acid Phosphatase $\left(\mu \mathrm{g} \mathrm{PNF} \mathrm{g}^{-1}\right.$ soil h$^{-1}$ ) & 5.64 & 46.86 & 41.99 & 30 & 5.85 & 1.71 & 11.65 & 20.53 & 19.26 & 42.4 & d \\
\hline 19 & Urease - Ure $\left(\mu \mathrm{g} \mathrm{NH}-\mathrm{N} \mathrm{g} \mathrm{g}^{-1} \mathrm{dwt}_{2 \mathrm{~h}^{-1}}\right)$ & 101.01 & 44.06 & 91.76 & 216.87 & 173.05 & 292.8 & 337.34 & 179.56 & 113.31 & 56.5 & d \\
\hline
\end{tabular}

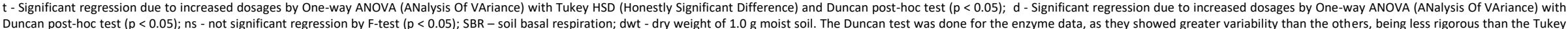
test.

Table 2. The permutational multivariate analysis of variance (PERMANOVA) of the explanatory model of lettuce plant development as a function of soil biochemical attributes. For this purpose, Euclidean distance matrices were used in the Adonis test.

\begin{tabular}{|c|c|c|c|c|c|c|}
\hline & Df & SumsOfSqs & MeanSqs & F.Model & $\mathrm{R}^{2}$ & $\operatorname{Pr}(>\mathrm{F})$ \\
\hline Variables* & 11 & 2217.92 & 201.629 & 3.0354 & 0.78768 & 0.0282 \\
\hline Residuals & 9 & 597.84 & 66.427 & 0.21232 & & \\
\hline Total & 20 & 2815.76 & 1 & & & \\
\hline
\end{tabular}

*Variables corresponding to CAP vectors (Fig 1). Free permutations: 10000. Df - degrees of freedom. 

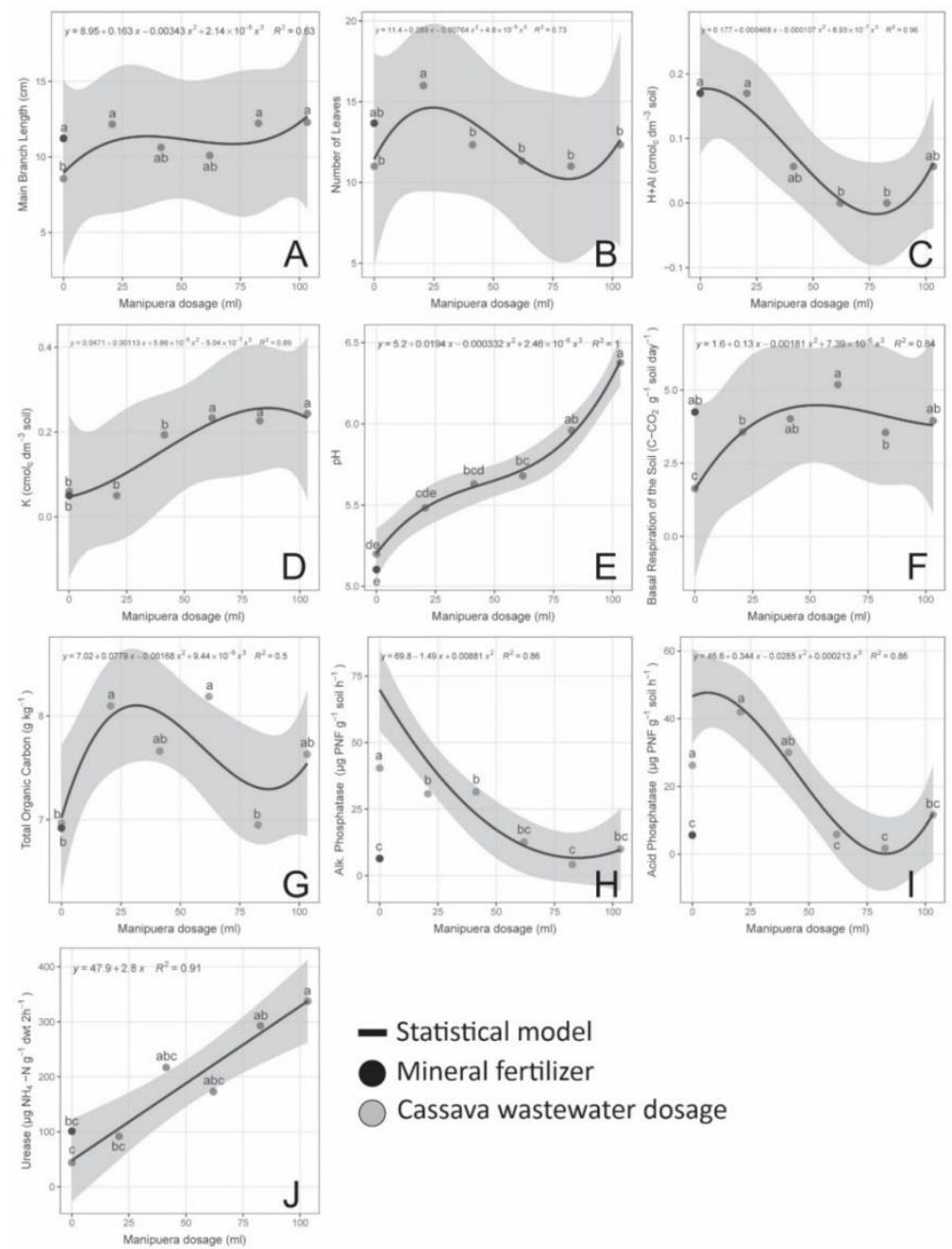

- Statistical model

Mineral fertilizer

Cassava wastewater dosage

Fig 1. Main contributions of cassava wastewater to the soil and lettuce plants, showing regression curves of variables showing significant responses to cassava wastewater dosage. Averages followed with the same small letters are similar, according to the tests in Table 1 ( $p \leq 0.05$ ). Black dots (out of the curve) represent the averages of additional treatment (NPK mineral fertilizer) while the gray dots are the progressive dosages of cassava wastewater in soil: $0 \%, 10 \%, 20 \%, 30 \%, 40 \%$ and $50 \%$ Field Capacity $\left(206.6 \mathrm{ml} \mathrm{kg}^{-1}\right.$ soil). The gray area around the loess smoothed-fit curve represents the confidence region (95\%).

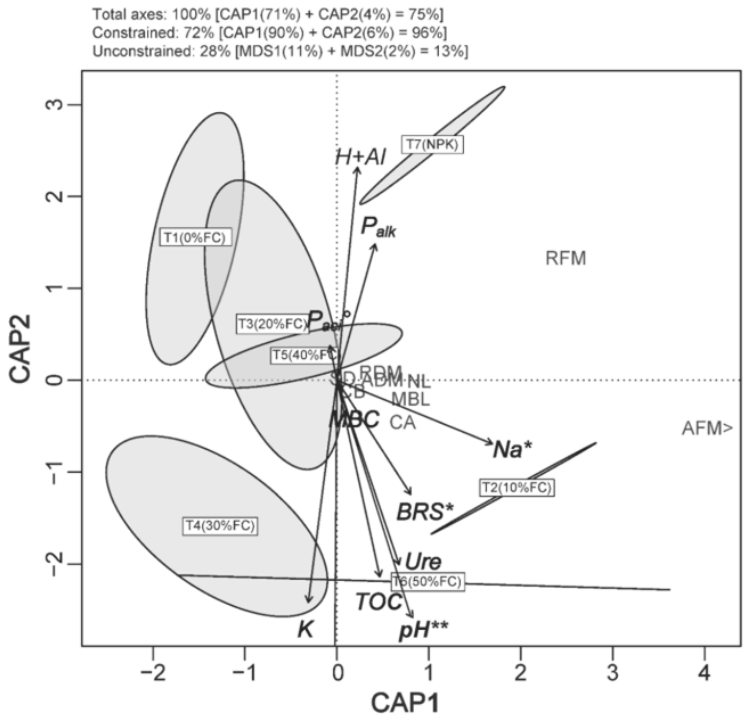

Fig 2. Canonical Analysis of Principal coordinates (CAP). Enzymatic activity and chemical attributes formed the explanatory matrix (Constraining) of the plant development model (Unconstraining) with the ellipses representing $30 \%$ of the observations. Variables: acid phosphatase (Pac), alkaline phosphatase (Palk), basal respiration of the soil (BRS), chlorophyll A (CA), chlorophyll B (CB), aerial dry matter (ADM), root dry matter (RDM), field capacity (FC), aerial fresh matter (AFM), root fresh matter (RFM), main branch length (MBL), microbial biomass carbon (MBC), number of leaves $(\mathrm{NL})$, stalk diameter (SD), total organic carbon (TOC). Significance of the vectors by the permutation test in multivariate analysis ( $p$-value): $0.001^{\prime * * \prime}$ $0.01^{\prime * \prime} 0.05^{\circ \prime \prime} 0.1$. 
Table 3. The permutational multivariate analysis of variance (PERMANOVA) of the explanatory model of plant attributes as a function of soil biochemical attributes (constraining variables).

\begin{tabular}{llllllll}
\hline & Df & SumsOfSqs & MeanSqs & F.Model & $\mathrm{R}^{2}$ & $\operatorname{Pr}(>\mathrm{F})$ & $\operatorname{Pr}(>\mathrm{F})$ \\
\hline Dosage & 1 & 77.8 & 77.8 & 1.147 & 0.028 & 0.305 & \\
$\mathrm{pH}$ & 1 & 891.4 & 891.4 & 13.145 & 0.317 & 0.001 & $* * *$ \\
$\mathrm{Na}$ & 1 & 321.6 & 321.6 & 4.743 & 0.114 & 0.036 & $*$ \\
$\mathrm{~K}$ & 1 & 11.9 & 11.9 & 0.175 & 0.004 & 0.818 & \\
$\mathrm{TOC}$ & 1 & 44.3 & 44.3 & 0.653 & 0.016 & 0.462 & \\
$\mathrm{MBC}$ & 1 & 6.3 & 6.3 & 0.093 & 0.002 & 0.924 & \\
Ure & 1 & 88.1 & 88.1 & 1.299 & 0.031 & 0.277 & \\
Palk & 1 & 33.3 & 33.3 & 0.490 & 0.012 & 0.544 & \\
Paci & 1 & 208.3 & 208.3 & 3.072 & 0.074 & 0.091 & $*$ \\
BRS & 1 & 454.8 & 454.8 & 6.706 & 0.162 & 0.017 & $*$ \\
Residuals & 10 & 678.1 & 67.8 & 0.241 & & & \\
Total & 20 & 2815.8 & 1 & & & & \\
\hline
\end{tabular}

$\mathrm{Df}=$ degrees of freedom. $\mathrm{TOC}=$ total organic carbon; $\mathrm{MBC}=$ microbial biomass carbon; $\mathrm{BRS}=$ basal respiration of the soil; Paci = soil acid phosphatase; Palk = soil alkaline phosphatase; Ure = soil urease activity. Signif. Codes ( $p-$ values): 0 ***' $0.001^{\prime * * \prime} 0.011^{\prime * \prime} 0.05$ '? 0.1 .

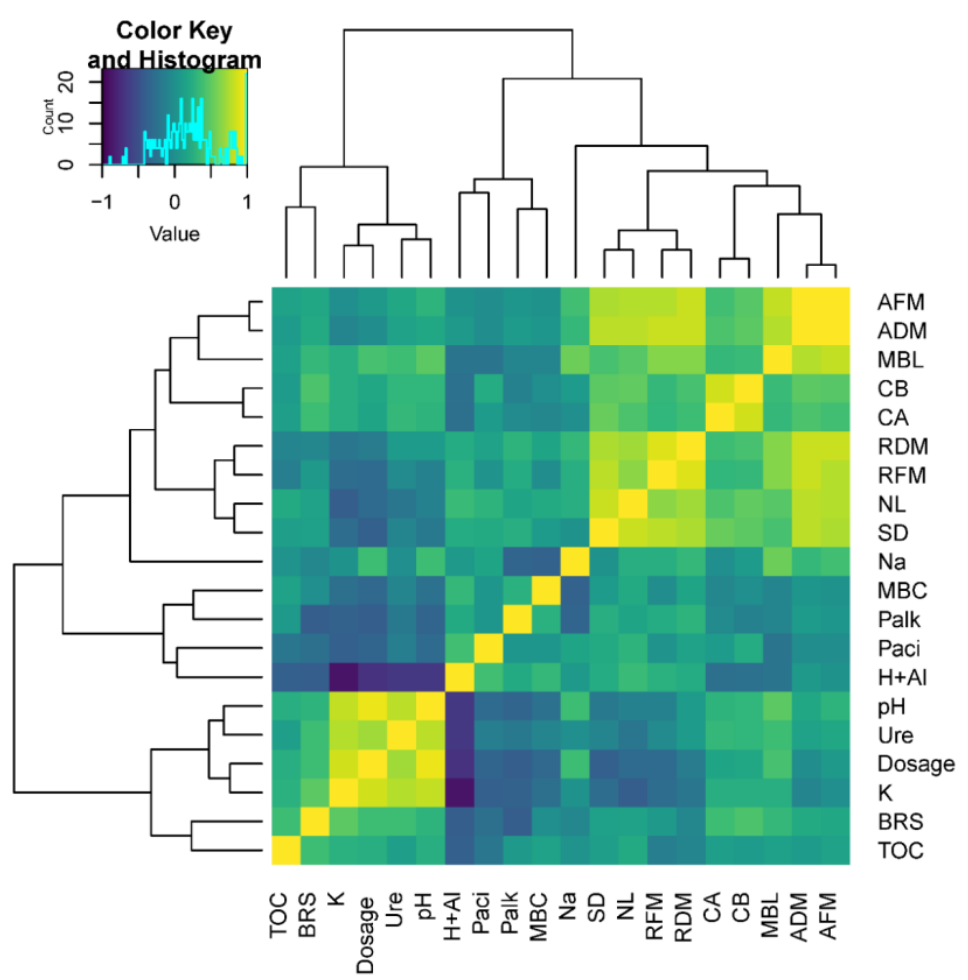

Fig 3. Heat map with correlation matrix of all variables and UPGMA dendrogram based on Pearson's $\mathrm{R}^{2}$, the Pearson product-moment correlation coefficient (PPMCC). Darker shades represent more negative correlations while lighter shades are the most positive. It is possible to observe stronger correlations $\left(\mathrm{R}^{2} \rightarrow[1]\right)$ between $\mathrm{pH}$, urease activity and $\mathrm{K}$ contents (positive), followed by the potential acidity $\left(\mathrm{H}^{+}+\mathrm{Al}^{3+}\right)$ and the Basal Respiration of the Soil (negative). See detailed abbreviations of the variables in Figure 2.

Table 4. Scores of plant variables in the main axes of the CAP ordering. Axis 1 (CAP1) was significant at or below $5 \%$ to reject the null hypothesis by forward F-tests for axes, with variance equal to 111 and an F-value of 3.03. Therefore, the variables with the highest CAP1 scores better explained the proposed model, and those that best respond to the biochemical changes studied in this soil.

\begin{tabular}{llll}
\hline & CAP1* & CAP2 & CAP3 \\
\hline MBL & 0.805 & -0.2 & -0.334 \\
NL & 0.896 & -0.01 & 0.408 \\
SD & 0.065 & 0.021 & 0.036 \\
AFM & 5.412 & -0.53 & -0.172 \\
RFM & 2.49 & 1.332 & 0.126 \\
ADM & 0.493 & 0.009 & 0.015 \\
RDM & 0.475 & 0.085 & 0.006 \\
CA & 0.717 & -0.45 & 0.668 \\
CB & 0.168 & -0.12 & 0.168 \\
\hline
\end{tabular}

*Significant by permutation test for CAP scale under reduced model $(p=0.029)$. Abbreviations are as shown in legend of the figure 1 . Free permutations: $1000 . \mathrm{MBL}=$ lettuce main branch length; $\mathrm{NL}=$ lettuce number of leaves; $\mathrm{SD}=$ lettuce stalk diameter; $\mathrm{AFM}=$ lettuce aerial fresh matter; $\mathrm{RFM}=$ lettuce root fresh matter; $\mathrm{ADM}=$ lettuce aerial dry matter; $\mathrm{RDM}=$ lettuce root dry matter; $\mathrm{CA}=$ chlorophyll $\mathrm{A} ; \mathrm{CB}=$ chlorophyll $\mathrm{B}$. 


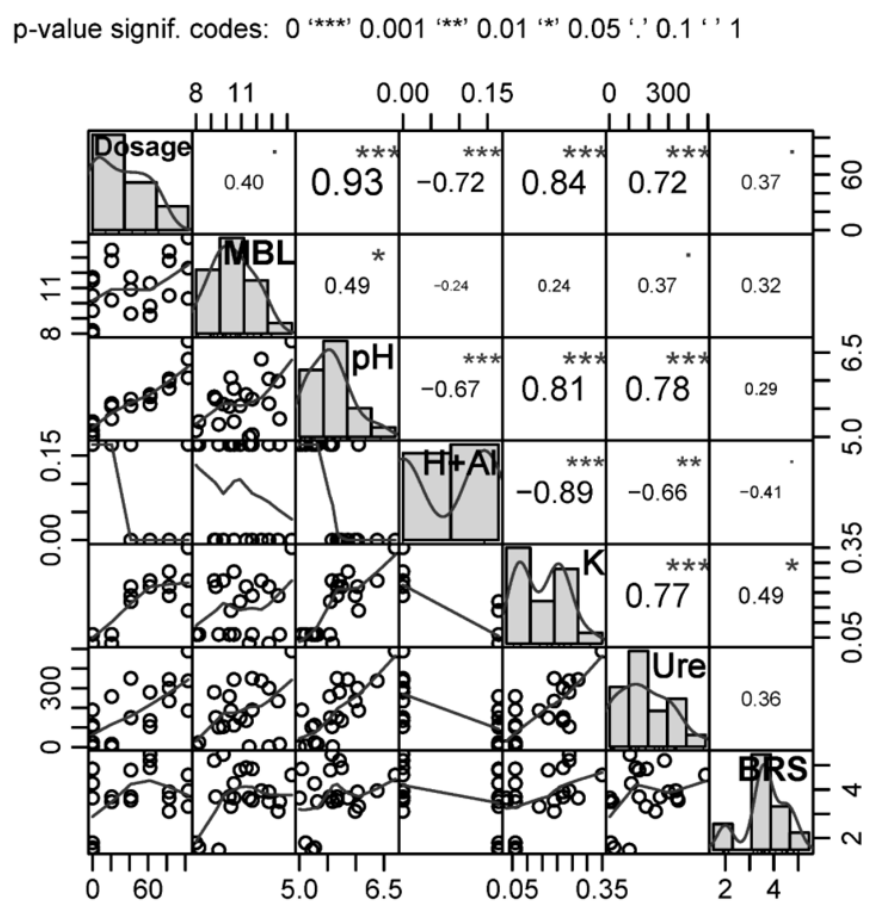

Fig 4. Chart of the correlation matrix (Pearson's $\mathrm{R}^{2}$ ) of the main variables studied, showing the bivariate dispersion graphs (below the bar graphs) and the respective adjusted correlations of each model ( $R_{2}$, above the bar graphs) followed by the indicators of significance, according to the multivariate permutation test. With progressive doses of $\mathrm{CW}$ there was a significant increase in $\mathrm{pH}, \mathrm{K}$ levels and urease activity in the soil, in addition to a significant reduction in total acidity $\left(\mathrm{H}^{+}+\mathrm{Al}^{3+}\right)$. These variables showed a close interaction with each other, supporting the existence of a statistical model that explains the fact (Fig 5). See detailed abbreviations of the variables in Figure 2.

Table 5. Estimates of coefficients and analysis of variance of the proposed linear model for urease activity as a function of $\mathrm{pH}$ and soil $\mathrm{K}^{+}$concentrations.

\begin{tabular}{llllll}
\hline & Estimate & Std. Error & t-value & $\operatorname{Pr}(>|\mathrm{t}|)$ & $*$ \\
\hline $\boldsymbol{\alpha}$ (intercept) & -569.6 & 241.5 & -2.359 & 0.036 & $*$ \\
$\boldsymbol{\beta}_{1}$ & 943.5 & 237.0 & 3.981 & 0.002 & $*$ \\
$\boldsymbol{\beta}_{\mathbf{2}}$ & 105.2 & 47.7 & 2.205 & 0.048 & $*$ \\
\hline $\mathrm{R}^{2}{ }_{\text {ajs. }}=0.91$ & Yurease & $\boldsymbol{\alpha}+\boldsymbol{\beta}_{1}(\mathrm{~K})+\boldsymbol{\beta}_{\mathbf{2}}(\mathrm{pH})$ & & & \\
Signif. codes: $0.001^{* * \prime} 0.01^{* *^{\prime}} 0.05$ & & & & \\
\hline
\end{tabular}

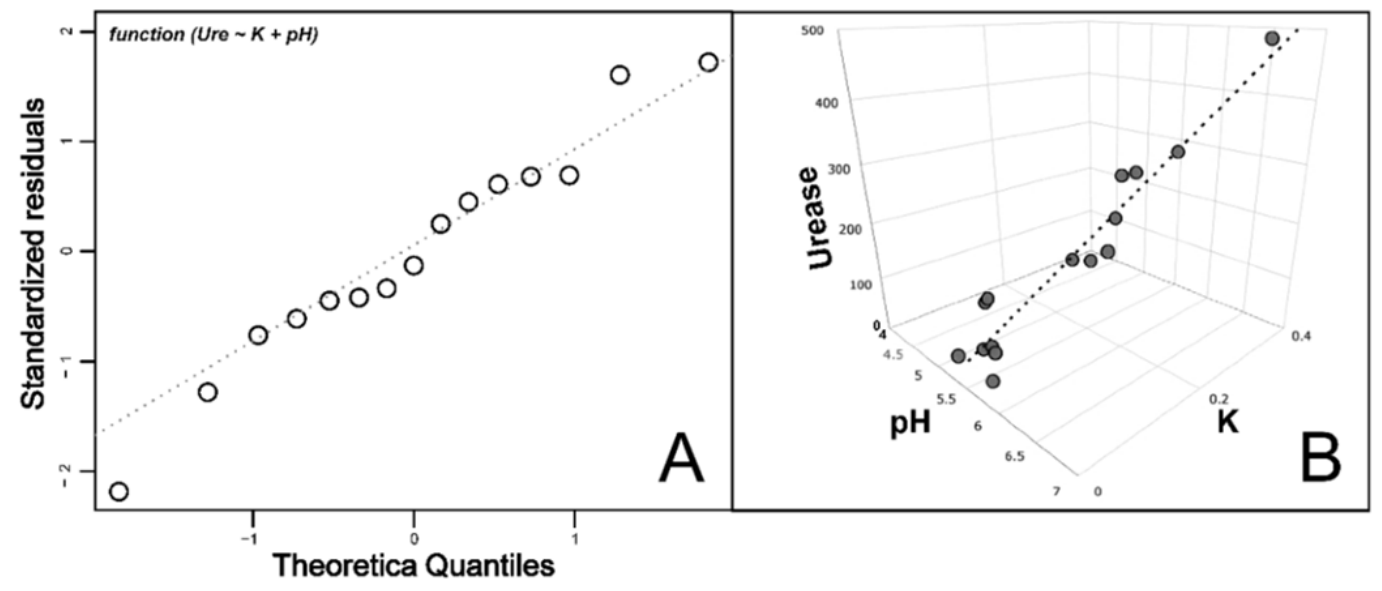

Fig 5. Q-Q plot showing strong evidence of residue normality $(A)$ and three-dimensional graphical representation (B) of the model with estimated regression curve for urease activity $\left(\mu \mathrm{g} \mathrm{NH}_{4}-\mathrm{N} \mathrm{g}^{-1} \mathrm{dwt} 2 \mathrm{~h}^{-1}\right)$ as a function of $\mathrm{pH}$ and soil $\mathrm{K}^{+}$ion concentrations (cmol $\mathrm{c}$ $\left.\mathrm{dm}^{-3}\right)$. 
revealing a significant response of urease activity as a function of $\mathrm{pH}$ and $\mathrm{K}^{+}$ions in the soil (Table 5). The distribution of standardized residuals showed a linear trend with respect to the theoretical quantiles of the standard normal distribution (Fig 5A). The model suggests that the higher the $\mathrm{pH}$ and $\mathrm{K}^{+}$ion concentrations, the higher the urease activity in soils with lettuce crop (Fig 5B).

\section{Discussion}

Lettuce plants showed significant signs of plant development as a result of $\mathrm{CW}$ application, highlighting the increase in fresh mass and the height of aerial parts at higher doses. Cassava wastewater is a macronutrient-rich by-product, especially in terms of $\mathrm{N}, \mathrm{K}_{2} \mathrm{O}, \mathrm{Mg}, \mathrm{P}_{2} \mathrm{O}_{5}, \mathrm{Ca}$ and $\mathrm{S}$, in addition to the micronutrients $\mathrm{Zn}, \mathrm{Cu}, \mathrm{Fe}, \mathrm{Mn}$, having also a low $\mathrm{C}: \mathrm{N}$ ratio (6.5:1) (Ribas et al., 2010). These characteristics partly explain the positive response of the crop to its application in the soil and encourage studies on its use as a biofertilizer.

Dantas et al. (2014) have demonstrated that increasing doses of CW (between 8.5 and $136 \mathrm{~m}^{3} \mathrm{ha}^{-1}$ ) resulted in a progressive and significant increase in the fresh mass of sunflower plants cultivated in a Dystrophic Red-yellow Latosol (oxisol), and also in $\mathrm{K}^{+}, \mathrm{Ca}^{2+}, \mathrm{Mg}^{2+}, \mathrm{Na}^{+}$, and $\mathrm{pH}$ levels, indicating an optimum dose of about $68 \mathrm{~m}^{3} \mathrm{ha}^{-1}$ to improve the chemical attributes of the soil. These results were similar to those of the present study, where the interval between $10 \%$ and $50 \%$ FC (the minimum and maximum dosages) corresponded to the application of $\mathrm{CW}$ between 15.7 and $78.5 \mathrm{~m}^{2} \mathrm{ha}^{-1}$, considering the soil layer of $20 \mathrm{~cm}$ (Dantas et al., 2014).

The number of lettuce leaves was the plant parameter that varied most significantly (Fig $1 \mathrm{~B}$ ), reaching a maximum number between $10 \%$ and $15 \%$ FC (15.7 to $\left.23.5 \mathrm{~m}^{3} \mathrm{ha}^{-1}\right)$. A similar result was observed by Duarte et al. (2012), who, using different doses of CW in a Dystrophic Regolithic Neosol (Entisol) cultivated with lettuce, observed a maximum number of leaves at the $25 \mathrm{~m}^{3} \mathrm{ha}^{-1}$ application. In this case, it was shown that NL decreased quadratically with increased dosage and after doses from $45 \mathrm{~m}^{3} \mathrm{ha}^{-1}$ also significantly reduced the leaf area, height, and the fresh and dry matter of the aerial parts. In the present study, a similar result was observed for the length of the main branch (Fig 1A), with a maximum of $15.7 \mathrm{~m}^{3} \mathrm{ha}^{-1}(10 \% \mathrm{FC})$ and a minimum of 47.1 $\mathrm{m}^{3} \mathrm{ha}^{-1}(30 \% \mathrm{FC})$, growing again after this dosage, which indicates efficient sensitivity of the lettuce to $\mathrm{CW}$ applications.

Overall, from multivariate analysis, $\mathrm{CW}$ was observed to be a viable alternative to increase $\mathrm{pH}$, exchangeable potassium, TOC, SBR and Ure activity in the soil. This is justified by the fact that these vectors closely follow the dosage vector, pointing to the highest concentration of $\mathrm{CW}(50 \% \mathrm{FC})$ while moving away from the negative control and mineral fertilizer (Fig 2). A similar result was found by Bezerra et al. (2019) in a sandy soil cultivated with Brachiaria brizantha in northeastern Brazil, who showed that increasing $\mathrm{CW}$ doses in the $0-20 \mathrm{~cm}$ layer resulted in increasing quadratic and linear responses to $\mathrm{pH}$ and $\mathrm{K}^{+}$, respectively, reaching up to $120 \mathrm{~m}^{3} \mathrm{ha}^{-1}$, representing a volume of about $76 \% \mathrm{FC}$ of soil used in the present study.

$\mathrm{pH}$ is the isolated variable that most influences the availability of nutrients in soil, having an optimal range between 6.0 and 6.5 , where there is also a reduction of one of the main limitations of agricultural production, exchangeable aluminum (Malavolta et al., 1997). In the present study, the $\mathrm{pH}$ started to reach this interval from the $\mathrm{CW}$ dosage of $87.3 \mathrm{ml} \mathrm{kg}^{-1}$ of soil, about $42.2 \% \mathrm{FC}$, reaching pH 6.4 at $50 \%$ FC (Fig 1E).

The introduction of bases into the soil, from the $\mathrm{CW}$, also favors an increase in $\mathrm{pH}$ due to the adsorption of ions, which displaces the $\mathrm{Al}^{3+}$ and $\mathrm{H}^{+}$cations in the soil solution. In this case, the aluminum precipitates, mainly in the $\mathrm{Al}_{2}\left(\mathrm{SO}_{4}\right)^{3}$ form, reducing the potential acidity of the soil (Souza et al., 2007).

The effects of acidity on plants are mainly related to the activities of $\mathrm{K}^{+}, \mathrm{Ca}^{2+}, \mathrm{Mg}^{2+}, \mathrm{SO}_{4}{ }^{2-}$, and $\mathrm{H}_{2} \mathrm{PO}^{4-}$ anions (Alleoni et al., 2010; Hashimoto et al., 2010). Under these conditions, the application of $\mathrm{CW}$ at $30 \%$ FC was the treatment that showed the most significant benefits for soil fertility, annulling the effects of potential acidity (Fig 1C) and promoting significant increases in $\mathrm{K}_{2} \mathrm{O}$ content, going from 0.05 in the control treatment to $0.24 \mathrm{cmol}_{c} \mathrm{dm}^{-3}$ at the dosage of $50 \%$ FC (Fig 2D). According to Malavolta et al. (1997), an exchangeable potassium content above $0.2 \mathrm{cmol}_{\mathrm{c}}$ $\mathrm{dm}^{-3}$ is considered high and adequate to meet the demand of most crops, showing the potential of $\mathrm{CW}$ as a natural fertilizer with multiple benefits for plants.

In addition to improvements in soil fertility, CW proves to be a potential natural stimulant of the metabolic activity of microorganisms, a fact evidenced by the quadratic increase in the basal breathing rate with a peak of $5.2 \mathrm{mg} \mathrm{CO}_{2} \mathrm{~g}^{-1}$ day ${ }^{1}$ at a dosage of $30 \%$ FC (Fig $1 \mathrm{~F}$ ). This same condition was observed for the total organic carbon content (TOC), reaching a maximum value of $8.2 \mathrm{~g} \mathrm{~kg}^{-1}$ at $30 \% \mathrm{FC}$ (Fig 1G), strengthening this argument.

The relationship between TOC and potential acidity is not coincidental, since the TOC content also controls the activity of aluminum in the soil solution (Ferro-Vázquez et al., 2014; Hagvall et al., 2015). According to Ritchie et al. (1988), the complexation of aluminum with organic molecules dissolved in solution is generally stronger than that of inorganic binders. Guibaud et al. (2000) have demonstrated that even at the $\mathrm{pH}$ range favorable to less soluble forms of aluminum (5.5-6.0), organic matter acts to prevent its precipitation. However, CW applied at high quantities to the soil can show indirect deleterious effects of nutrients, such as potassium. The high biochemical oxygen demand (BOD) and the concentrations of hydrocyanic acid and micronutrients are challenges for the treatment of these effluents, being the main limiting factors of their use as biofertilizer (Ribas et al., 2010). These characteristics emphasize the need for studies on the mitigation of the deleterious effects of $\mathrm{CW}$, allowing its application to soil in greater quantities.

Studying the effect of cassava plant effluents in Nigeria, Ukaegbu-Obi et al. (2018) reported deleterious effects of excess cassava wastewater on soil structure and quality, affecting its microbiota and inducing the predominance of the bacterial genera Aspergillus spp., Penicillium spp., Pseudomonas spp., and Bacillus spp. Izah et al. (2017) also identified in abundance these genera in cassava effluent soils, including also the species Staphylococcus aureus, Pseudomonas aeruginosa, Enterobater sp., Micrococus sp., Proteus sp., and the fungi Saccharomyces cerevisiae, Penicillin sp., Aspergillus sp., Rhizopus sp., and Mucor sp.

These results give rise to the possibility of selecting tolerant microorganisms for bioremediation of soils contaminated by cassava wastewater and the use of CW in large quantities for irrigation of crops after appropriate treatment, such as in anaerobic reactors also intended for biogas production (Watthier et al., 2019). A study by Izah et al. (2017) also 
demonstrated a significant reduction in the abundance of microbial communities in soils that received $\mathrm{CW}$, although the diversity did not change. Those authors also recommended the treatment of effluents from factories to mitigate their harmful effects on microflora.

Another relevant fact was the reduction in the activities of acid and alkaline phosphatase due to $\mathrm{CW}$ dosage, with minimum values being reached between $30 \%$ and $50 \%$ FC (Fig $1 \mathrm{H}$ and Fig 1I). Ibe et al. (2014), studying the effect of cassava effluents on Nigerian soil, condemned their excessive use in both the dry and wet seasons, observing a negative effect on the activities of acid and alkaline phosphatases in the $15 \mathrm{~cm}$ layer. On the other hand, these authors reported a significant increase in urease activity in soils with excessive cassava wastewater, which also corroborated the present study (Fig 1J).

One of the most important points of this study was the high simultaneous correlation between the $\mathrm{CW}$ dosages, $\mathrm{pH}, \mathrm{K}_{2} \mathrm{O}$ content and urease activity in the soil (Fig 5), a result endorsed by regression analysis (Table 2). Fisher et al. (2017), quantifying genes that encode Ure in soils with pH gradients between 3.1 and 7.1, demonstrated that the rate of urea hydrolysis correlated positively and significantly with the $\mathrm{pH}$ and number of copies of $16 \mathrm{~S}$ rRNA and ureC genes, indicating that soils with $\mathrm{pH}$ closer to neutral selected more microorganisms capable of producing urease, especially bacteria. Corroborating these data, Ribas et al. (2010), studying the use of urea by corn plants, concluded that $\mathrm{CW}$ addition to soil significantly increased the absorption of nitrogen by plants, being another strong indication that the addition of cassava wastewater potentiates the activity of urease in soil.

The exchangeable potassium concentration in the soil was the only significant variable capable of complementing these results (Fig 5). Hess et al. (2006), studying the effect of $\mathrm{NH}^{4+}$ toxicity on Saccharomyces cerevisiae, demonstrated that genes related to nitrogen metabolism are affected by potassium limitation, highlighting the GAP1 and MEP2 genes, which encode the main carriers of $\mathrm{NH}^{4+}$ and amino acids in cells. This result is a strong signal that the high potassium content contained in $\mathrm{CW}$ is one of the main factors that potentiates the activity of ureases in the soil.

\section{Materials and methods}

\section{Characterization of soil and cassava wastewater}

For the execution of this experiment, Entisol (Soil Survey Staff, 2014) was collected from the $0-20 \mathrm{~cm}$ layer in a native forest of the semiarid region in Pernambuco state, Brazil. Preliminary soil analysis demonstrated the following characteristics: $\mathrm{pH} 4.5 ; \mathrm{P}\left(16.6 \mathrm{mg} \mathrm{dm}^{-3}\right)$; $\mathrm{Ca}\left(0.80 \mathrm{cmol}_{\mathrm{c}} \mathrm{dm}^{-}\right.$ 3); $\mathrm{Al}\left(0.15 \mathrm{cmol}_{\mathrm{c}} \mathrm{dm}^{-3}\right) ; \mathrm{Na}\left(0.28 \mathrm{cmol}_{\mathrm{c}} \mathrm{dm}^{-3}\right) ; \mathrm{Mg}(0.80 \mathrm{cmolc}$ $\left.\mathrm{dm}^{-3}\right) ; \mathrm{K}\left(0.15 \mathrm{cmol}_{\mathrm{c}} \mathrm{dm}^{-3}\right)$; and $\mathrm{H}+\mathrm{Al}\left(1.8 \mathrm{cmol}_{\mathrm{c}} \mathrm{dm}^{-3}\right)$; field capacity $\left(206.6 \mathrm{~mL} \mathrm{dm}^{-3}\right)$; and density of soil $\left(1.52 \mathrm{~kg} \mathrm{dm}^{-3}\right)$.

The chemical composition of $\mathrm{CW}$ was characterized and described in Moura et al. (2018) as the following: pH 5.2, organic matter (1.2\%); soil humidity (98.2\%); N (7.0 $\left.\mathrm{mg} \mathrm{L}^{-1}\right)$;

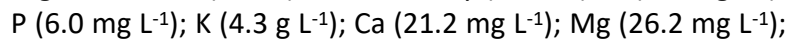
$\mathrm{S}\left(3.0 \mathrm{mg} \mathrm{L}^{-1}\right) ; \mathrm{Cu}\left(0.06 \mathrm{mg} \mathrm{L}^{-1}\right) ; \mathrm{Fe}\left(4.81 \mathrm{mg} \mathrm{L}^{-1}\right) ; \mathrm{Mn}(0.88 \mathrm{mg}$ $\left.\mathrm{L}^{-1}\right) ; \mathrm{Zn}\left(0.16 \mathrm{mg} \mathrm{L}^{-1}\right) ;$ and negligible traces of sodium.

\section{Experimental design}

Pots containing $4.0 \mathrm{~kg}$ of soil were cultivated with a commercial variety of lettuce plants (Lactuca sativa L.), namely Simpson. Three seeds were sown per pot, thinning to two plants five days after emergence.

The experimental design was completely randomized, with seven treatments and ten repetitions. Based on maximum soil water retention capacity, Field Capacity $(100 \%$ FC $=$ $206.6 \mathrm{ml} \mathrm{dm}-3$ ), the treatments corresponded to increasing dosage of Cassava Wastewater (CW): T1 - negative control (0\% FC), T2 - $20.7 \mathrm{ml}(10 \% \mathrm{FC}) ; \mathrm{T} 3$ - $41.3 \mathrm{~mL}$ (20\% FC); T4 $62.0 \mathrm{~mL}(30 \% \mathrm{FC}) ; \mathrm{T} 5-82.6 \mathrm{~mL}(40 \% \mathrm{FC}), \mathrm{T} 6-103.3 \mathrm{~mL}(50 \%$ $\mathrm{FC}$ ), and T7 (additional treatment) - Application of $1.0 \mathrm{~g}$ of mineral fertilizer $(20 \% \mathrm{~N}, 10 \% \mathrm{P}$, and $20 \% \mathrm{~K})$ per pot. Sowing occurred 15 days after treatment and the plants were grown for 28 days after emergence in a greenhouse at room temperature and irrigated daily with distilled water to keep the soil at field capacity.

\section{Plant analysis and soil chemical attributes}

The chlorophyll A (CA) and chlorophyll B (CB) content was determined with a clorofiLOG electronic chlorophyll meter, (model CFL1030, FALKER - Brazil). After removal, plants were measured to determine aerial fresh matter (AFM), root fresh matter (RFM), main branch length (MBL), number of leaves (NL), and stalk diameter (SD); aerial dry matter (ADM) and root dry matter (RDM) were measured after drying in a forced ventilation oven at $65^{\circ} \mathrm{C}$ until their weights remained stable.

The soil $\mathrm{pH}$ was determined in water (proportion 1:2.5) and $\mathrm{P}, \mathrm{Na}^{+}, \mathrm{K}^{+}, \mathrm{Ca}^{2+}, \mathrm{Mg}^{2+}$, and $\mathrm{Al}^{3+}$ content, as well soil potential acidity $\left(\mathrm{H}^{+}+\mathrm{Al}^{3+}\right)$, following the methodology proposed by Silva (2009).

The inorganic labile $\mathrm{P}, \mathrm{Na}^{+}$, and $\mathrm{K}^{+}$were extracted using Mehlich-1 solution $\left(0.0125 \mathrm{~mol} \mathrm{H}_{2} \mathrm{SO}_{4} \mathrm{~L}^{-1}+0.05 \mathrm{~mol} \mathrm{HCl} \mathrm{L}^{-1}\right)$. $\mathrm{P}$ was quantified using a spectrophotometer, and $\mathrm{Na}^{+}$and $\mathrm{K}^{+}$ were determined by flame photometry. $\mathrm{Ca}^{2+}, \mathrm{Mg}^{2+}$, and $\mathrm{Al}^{3+}$ were extracted with $1.0 \mathrm{~mol} \mathrm{KCl} \mathrm{L}^{-1}$ solution, where the first two were determined by atomic absorption spectrometry. Potential acidity was determined using calcium acetate ( $\mathrm{Ca}$ $\left.\left(\mathrm{CH}_{3} \mathrm{OO}\right)_{2} \mathrm{H}_{2} \mathrm{O}\right)$ at $\mathrm{pH}$ 7.0. In addition, $\mathrm{Al}^{3+}$ was determined by titration with $0.025 \mathrm{~mol} \mathrm{NaOH} \mathrm{L}^{-1}$, using bromothymol blue as indicator. In all extractions, $5.0 \mathrm{~g}$ of soil was used for 50 $\mathrm{mL}$ of extractive solution (relation 1:10).

Total organic carbon, microbial biomass, basal respiration, and enzymatic activities of soil cultivated with lettuce and treated with cassava wastewater

Soil from $2 \mathrm{~mm}$ around the roots (rhizosphere) was used to determine the total organic carbon (TOC) and microbial biomass carbon (MBC) content, in addition to soil basal respiration (SBR), and the urease activity (Ure) (EC 3.5.1.5) and acid (Pac) (EC 3.1.3.2) and alkaline (Palk) (EC 3.1.3.1) phosphatases.

The methodology proposed by Yeomans and Bremner (1988) was used to quantify $\mathrm{TOC}$ and $\mathrm{MBC}$ by irradiation and extraction adding $80 \mathrm{~mL}$ of $0.5 \mathrm{M} \mathrm{K}_{2} \mathrm{SO}_{4}$ in $20 \mathrm{~g}$ of soil. The $\mathrm{MBC}$ in extract values were obtained by colorimetry (Bartlett and Ross, 1988). The phosphatase activity was measured according to the methodology of Eivazi and Tabatabai (1977), using p-Nitrophenyl Phosphate as a substrate. Urease activity was measured according to Kandeler and Gerber (1988), using urea as a substrate. The absorbance was measured by spectrophotometer (Libra S22, Biochrom, Cambridge - England), at wavelengths ( $\lambda$ ) of $400 \mathrm{~nm}$ and 690 $\mathrm{nm}$ for phosphatases and urease, respectively. 


\section{Statistical analyses}

Exploratory analyses, graphs and multivariate statistics were computed using the R software ( $v$ 3.4.3). The Constrained Analysis of Principal Coordinates (CAP) and Permutational Multivariate Analysis of Variance (PERMANOVA) were executed through the 'vegan' library using the Euclidean distance matrix data.

The correlations were calculated based on Pearson's algorithm, where the heatmaps were constructed with the 'heatmaply' library, and chart correlation by the 'PerformanceAnalytics' and 'ggplot2' libraries. The ANOVA of the paired data was done through the library 'ExpDes' with Tukey HSD (Honestly Significant Difference) and Duncan post-hoc tests done for possible significance in F-test ( $p \leq$ 0.05 ), with the regression graphs traced in these cases, using the resources of the 'ggplot2' library. The three-dimensional models were designed with the help of the 'plotly' library.

\section{Conclusion}

Cassava wastewater (CW) favored the development of lettuce plants in relation to the length of the branches, number of leaves and chlorophyll concentrations when it is applied from $10 \%$ of the field capacity (FC). The most expressive gains were in primary growth and in the aerial fresh mass, corresponding to a $40 \%$ increase compared to the control. This condition also raised the $\mathrm{pH}$ and the exchangeable $\mathrm{K}$ content to the optimal range and simultaneously neutralized the potential soil acidity. The application of $30 \%$ FC was optimal dosage for basal respiration and total organic carbon. Urease activity grew linearly with CW dosage, presenting a significant and directly proportional relationship with the $\mathrm{pH}$ and the exchangeable potassium of the soil. This study endorses the use of CW as a low-dose biofertilizer to improve the quality of sandy soil. Given these considerations, $20.7 \mathrm{ml} \mathrm{CW} \mathrm{dm}^{-3}$ (10\% FC) was the dose that improved the greatest number of phenotypic variables of the plants. However, higher doses contributed more to increases in $\mathrm{pH}$ (reducing $\mathrm{H}^{+}+\mathrm{Al}^{3+}$ ), $\mathrm{K}$ levels, urease activity and basal respiration in the soil, especially $62 \mathrm{ml} \mathrm{CW}$ $\mathrm{dm}^{-3}$ (30\% FC). These soil benefits might be better reflected in the crop at a later phenological stage, when it has greater nutritional demand, a hypothesis that will be tested in the future by reproducing this experiment in the field.

\section{Acknowledgements}

This study was supported by the CNPq (Conselho Nacional de Desenvolvimento Científico e Tecnológico (313174/20180 ; 426497/2018-0) and CAPES (Coordenação de Aperfeiçoamento de Pessoal de Nível Superior - Brasil under Finance Code 001). Finally, we thank the anonymous reviewers for the help and comments that have contributed to the improvement of the manuscript.

\section{Declaration of interest}

There is no conflict of interest by the authors.

\section{References}

Alleoni LRF, Cambri MA, Caires EF, Garbuio FJ (2010) Acidity and aluminum speciation as affected by surface liming in tropical no-till soils. Soil Sci Soc Am J. 74(3):1010-2017.
Andrade CJ, Andrade LM, Rocco SA, Sforça ML, Pastore GM, Jauregi $P$ (2017) A novel approach for the production and purification of mannosylerythritol lipids (MEL) by Pseudozyma tsukubaensis using cassava wastewater as substrate. Sep Purif Technol. 180:157-167.

Barreto MT, Magalhães AG, Rolim MM, Pedrosa EM, Duarte ADS, Tavares UE (2014) Growth and accumulation of macronutrients in maize plants biofertilized with cassava wastewater. Rev Bras Eng Agr Amb. 18 (5):487-494.

Bartlett RJ, Ross DS (1988) Colorimetric determination of oxidizable carbon in acid soil solutions. Soil Sci Soc Am J. 52(4):1191-1192.

Bezerra MGS, Silva GGC, Difante GS, Neto JVM, Oliveira EMM, Morais EG (2019) Chemical attributes of soil under cassava wastewater application in marandugrass cultivation. Rev Bras Eng Agr Amb. 23(8):579-585.

Dantas MSM, Rolim MM, Duarte ADS, Lima LED, Silva MMD (2017) Production and morphological components of sunflower on soil fertilized with cassava wastewater. Rev Ceres. 64(1): 77-82.

Dantas MSM, Rolim MM, Duarte AS, Silva NFF, Pedrosa EMR, Dantas DC (2014) Chemical attributes of soil fertilized with cassava mill wastewater and cultivated with sunflower. Sci. World J. 279312:10.

Duarte AS, Silva EFF, Rolim MM, Ferreira RFAL, Malheiros SMM, Albuquerque FC (2012) Use of different doses of cassava wastewater in lettuce crop in substitution of mineral fertilizer. Rev Bras Eng Agr Amb. 16(3):262-267.

Eivazi F, Tabatabai MA (1977) Phosphatases in soils. Soil Biol Biochem. 9(3):167-172.

Ferro-Vázquez C, Nóvoa-Muñoz JC, Costa-Casais $M$, Klaminder J, Martínez-Cortizas A (2014) Metal and organic matter immobilization in temperate podzols: a highresolution study. Geoderma. 217:225-234.

Fisher KA, Yarwood SA, James BR (2017) Soil urease activity and bacterial ureC gene copy numbers: effect of $\mathrm{pH}$. Geoderma. 285:1-8.

Gomes SD, Fuess LT, Gomes PCF, Zaiat M (2016) Bacteriocins of lactic acid bacteria as a hindering factor for biohydrogen production from cassava flour wastewater in a continuous multiple tube reactor. Int J Hydrogen Energ. 41(19):81208131.

Guibaud G, Gauthier G, Ayele J (2000) Role of natural organic matter in the mobility of aluminium ions in rivers in the Limousin region (France). Agronomie 20:577-590.

Hagvall K, Persson P, Karlsson T (2015) Speciation of aluminum in soils and stream waters: the importance of organic matter. Chem Geol. 417:32-43.

Hashimoto Y, Smyth TJ, Israel DW, Hesterberg D (2010) Lack of soybean root elongation responses to micromolar magnesium additions and fate of root-exuded citrate in acid soils. J Plant Nutr. 33:219-239.

Ibe IJ, Ogbulie NJ, Odum DC, Onyirioha1 C, Peter-Ogu P, Okechi RN (2014) Effects of Cassava mill effluent on some groups of soil bacteria and soil enzymes. Int J Curr Microbiol App Sci. 3(10): 284-289.

Izah SC, Aigberua AO (2017) Assessment of microbial quality of cassava mill effluents contaminated soil in a rural community in the Niger Delta, Nigeria. EC Microbiol. 4:132-140.

Jiao J, Li J, Bai Y (2018) Uncertainty analysis in the life cycle assessment of cassava ethanol in China. J Clean Prod. 206:438-451. 
Kandeler E, Gerber H (1988) Short-term assay of soil urease activity using color-imetric determination of ammonium. Biol Fertil Soils. 6:68-72.

Malavolta E, Vitti GC, Oliveira SAE (1997) Avaliação do estado nutricional das plantas: princípios e aplicações, 2nd edn. Potafos, Piracicaba, 319 p.

Moura AS, Medeiros EV, Oliveira JE, Franca RF, Lira AD, Martins-Filho AP, Badji CA (2018) Does cassava wastewater with a short incubation time affect soil organic carbon, microbial community and enzymatic activities? Catena. 163:354-360.

Nasu EDGC, Formentini HM, Furlanetto C (2015) Effect of manipueira on tomato plants infected by the nematode Meloidogyne incognita. Crop Prot. 78:193-197.

Oliveira FJS, Jucá JFT (2004) Acúmulo de metais pesados e capacidade de impermeabilização do solo imediatamente abaixo de uma célula de um aterro de resíduos sólidos. Eng Sanit Ambient. 9: 211-217.

Ratnadewi AAI, Santoso AB, Sulistyaningsih E, Handayani W (2016) Application of cassava peel and waste as raw materials for xylooligosaccharide production using endoxylanase from Bacillus subtilis of soil termite abdomen. Procedia Chem. 18:31-38.

Ribas MMF, Cereda MP, Villas-Boas RL (2010) Use of cassava wastewater treated anaerobically with alkaline agents as fertilizer for maize (Zea mays, L). Braz Arch Biol Techn. 53:55-62.

Ritchie GSP, Nelson MP, Whitten MG (1988) The estimation of free aluminum and the complexation between fluoride and humate anions for aluminum. Commun Soil Sci Plan. 19:857-871.

Rosa PRF, Gomes BC, Varesche MBA, Silva EL (2016) Characterization and antimicrobial activity of lactic acid bacteria from fermentative bioreactors during hydrogen production using cassava processing wastewater. Chem Eng J. 284:1-9.
Santos JFD, Sousa CDS, Soares ACF, Lima FDS, Barbosa DHSG (2016) Actinobacteria and organic fertilizers for management of the nematode Scutellonema bradys in yam plants. Rev Caatinga. 29(3): 548-558.

Santos JS, Lima VLA, Borges-Júnior, JCF, Silva LVBD, Azevedo CAV (2010) Mobilidade de solutos em colunas de solo com água residuária doméstica e de suinocultura1. Rev Bras Eng Agríc Ambient. 14(11):1226-1233.

Scherer K, Granada CE, Stülp S, Sperotto RA (2016) Avaliação bacteriológica e físico-química de águas de irrigação, solo e superfície (Lactuca sativa L). Rev Amb Água. 11(3):665-675

Silva FC (ed) (2009) Manual de análises químicas de solos, plantas e fertilizantes, 2nd edn. Embrapa Informática Agropecuária, Brasília, $230 \mathrm{p}$.

Souza DMG, Miranda LN, Oliveira SA (2007) Acidez do solo e sua correção. In: Novais RF, Aalvarez VVH, Barros NF, Fontes RLF, Cantarutti RB, Lima JC (eds). Fertilidade do solo. SBCS, Viçosa, pp 205-275.

Ukaegbu-Obi KM, Appeh OG, Itaman OV, Nwosu PC (2018) Microbial and physico-chemical analyses of soil receiving cassava mill wastewater in Umudike, Abia State, Nigeria. Niger J Biotechnol. 35(2):99-107.

Watthier E, Andreani1 CL, Torres DGB, Kuczman O, Tavares MHF, Lopes DD, Gomes SD (2019) Cassava Wastewater Treatment in Fixed-Bed Reactors: Organic Matter Removal and Biogas Production. Front Sustain Food Syst. 3:1-8.

Ye F, Li Y, Lin Q (2017) Modeling of China's cassava-based bioethanol supply chain operation and coordination. Energy. 120:217-228.

Yeomans JC, Bremner JM (1988) A rapid and precise method for routine determination of organic carbon in soil. Commun Soil Sci Plan. 19:1467-1476.

Zainuddin, I M, Fathoni, A, Sudarmonowat, E, Beeching, J R, Gruissem, W, Vandersurn, H (2018) Cassava post-harvest physiological deterioration: From triggers to symptoms. Postharvest Biol Tec. 142:115-123. 